\title{
The nonproliferation of states: A reply to Pascal Boniface
}

\section{Scott Pegg}

To cite this article: Scott Pegg (1999) The nonproliferation of states: A reply to Pascal Boniface, , 22:2, 139-147, DOI: 10.1080/01636609909550393

To link to this article: https://doi.org/10.1080/01636609909550393

Published online: 07 Jan 2010.

Submit your article to this journal $\square$

Џll Article views: 40

Citing articles: 1 View citing articles 5 


\section{The Nonproliferation of States: A Reply to Pascal Boniface}

$I_{n}$ gues the case that, in addition to the more visible threats emanating from the proliferation of nuclear, chemical, and biological weapons, the contemporary world also faces a growing danger from the "proliferation of states." While Boniface draws our attention to an important issue and raises a number of interesting and original points, his economically deterministic analysis of secession is fundamentally flawed. Instead of witnessing Boniface's "dizzying rate" of secession, the coming years are likely to serve up only the much more modest phenomenon of slow, occasional, and largely unthreatening growth in the number of new sovereign states.

In Boniface's vision, states are "exploding before our very eyes, incapable of preserving themselves against the irresistible desire of ethnic groups to constitute states of their own." As such, the end result is a pace of state proliferation that "seems to be out of control." He arrives at this doomsday scenario on the basis of six related misconceptions.

First, contrary to Boniface's assertion, states are quite capable of preserving themselves. The mortality rate of contemporary states is extremely low. Much of this may have to do with the international community's reflexive support for fixed territorial borders, but the fact remains that most states are far from helpless when confronted with ethnic or nationalist challenges to their rule. The successful transformation of El Salvador's Farabundo Martí National Liberation Front (FMLN) into a peaceful political party, the parlous state of the secessionist campaigns in Southern Sudan and south-

Scott Pegg is an assistant professor at the Department of International Relations of Bilkent University, Ankara, Turkey.

Copyright $(1) 1999$ by The Center for Strategic and International Studies and the Massachusetts Institute of Technology

The Washington Quarterly • 22:2 pp. 139-147. 
eastern Turkey, and the recent cease-fires announced in Northern Ireland and the Basque country provide examples of states successfully confronting well-entrenched secessionist or dissident movements.

Second, Boniface equates all minority grievances with secession, ignoring the more common aim of self-determination and thus exaggerating the true extent of the secessionist threat in the world today. In Nigeria, for example, the Ogoni people prefaced their demand for political autonomy in the Ogoni Bill of Rights with the statement, "Now, therefore, while reaffirming our wish to remain a part of the Federal Re-

The mortality rate of contemporary states is extremely low. public of Nigeria . . . ." Further on this demand for political autonomy is specified to include "adequate and direct representation as of right in all Nigerian national institutions." Referencing these points, Ken SaroWiwa, the subsequently executed Ogoni leader who had been a vocal opponent of the Biafran secessionist attempt more than 20 years earlier, sarcastically noted that "only an idiot or a man fishing for trouble could ever construct those words as secessionist."

Third, Boniface appears to view the decade of 1990s as more exceptional in terms of the number of secessionist bids it hosted than it really is, describing it as "the decade of secession." But in evaluating the data produced by the "Minorities at Risk" project, Ted Robert Gurr argues quite to the contrary that "tendencies toward ethnic fragmentation have characterized world politics since the 1960s and have long been evident to observers who were not preoccupied by Cold War issues.... Serious new conflicts generated by aspirations for independence and autonomy have thus far been confined almost entirely to the Soviet and Yugoslav successor states."

Secessionist movements have long been a feature of international politics and they will continue to be so in the future. Their salience in the late 1990 s is not dramatically different, however, from what it was in the 1960 s or 1970s.

Fourth, Boniface also claims that a declining external threat environment in the post-Cold War era is a spur to future secessionist movements, using the former Yugoslavia as a paradigmatic example of what the future holds. A more benign external environment might make it harder to justify state cohesion, but Boniface again exaggerates its importance. As recent tensions between such varied countries as Ecuador and Peru, Eritrea and Ethiopia, India and Pakistan, and Syria and Turkey illustrate, many states still face challenging external threat environments. Indeed, one can argue that the continent of Africa as a whole faces a much more challenging external secu- 
rity environment today than it ever did during the Cold War. Thus a declining external threat environment is by no means a generic phenomenon across all regions or one that we should expect to see leading to the creation of large numbers of new states. ${ }^{4}$

A fifth mistake that leads Boniface to overestimate the secessionist threat is his emphasis on "the baneful effects of an untrammeled application of the right of self-determination." Were there any prospect that such an untrammeled right to self-determination was on the horizon, Boniface would be correct in his assessment of the future prospects for state proliferation. Nothing in the history of self-determination, however, indicates that such an unlimited right to self-determination will ever take hold in international relations. The post-1945 version of self-determination was expressed in universal terms in Articles 1 (2) and 55 of the United Nations Charter but in reality was applied narrowly to just three groups: colonies, territories under military occupation, and apartheid regimes where majority African populations suffered institutionalized discrimination at the hands of white minority regimes. Thus Yorubas might find being ruled by Hausas just as "alien" as being ruled by the British, but they were not eligible to remedy this situation through a resort to the right of self-determination. Similarly, while black Rhodesians suffering under apartheid were entitled to exercise their right to self-determination, black southern Sudanese suffering institutionalized discrimination at the hands of Arabs were not. ${ }^{5}$

Sixth, Boniface also blindly accepts the so-called "domino theory," whereby the recognition granted to one secessionist movement anywhere necessarily sparks future secessionist attempts everywhere. History suggests otherwise: one can cite Norway's secession from Sweden, Iceland's secession from Denmark, Singapore's secession from Malaysia, and Bangladesh's secession from Pakistan as examples of the fact that one successful secession does not necessarily lead to new secession attempts in either the newly independent state, the former parent state, or the region. Eritrea's secession from Ethiopia may offer modest encouragement to Somaliland but it has in no way led to any wholesale redrawing of African borders.

Boniface appears to base his dire projections on an unwarranted linear extrapolation of present trends into the future. In his view, "as self-determination continues to eat away at the principle of territorial integrity in the years ahead, the tidal wave of state proliferation will gain force." ${ }^{\text {A }}$ A more nuanced view, however, would recognize that periods of state creation and changes in self-determination norms move in cyclical, rather than in linear, fashion.

J. Samuel Barkin and Bruce Cronin have laid out one persuasive view of this process. Legitimacy in the international system, they argue, has tradi- 
tionally oscillated between two different forms of sovereignty: state sovereignty, which links sovereign authority to a defined territory, and national sovereignty, which links sovereign authority to a defined population. As they see it, the tensions inherent in these two different conceptions of legitimacy are unlikely ever to be resolved. Rather, in a somewhat dialectical fashion, international orders that tend to favor one approach create tensions that often lead to fundamental reassessments in the next post-war settlement. Historically, Barkin and Cronin argue that the post-Napoleonic settlement favored the state, the post-World War I settlement favored the nation, and the post-World War II settlement favored the state, and that no definitive resolution has yet emerged in the post-Cold War period, although there does appear to be a move in the direction of increased national legitimacy. ${ }^{7}$

When viewed in cyclical, as opposed to linear, terms, the burst of state creation seen in the 1991-93 period should not lead inexorably to a future "tidal wave" of state proliferation, but, on the contrary, to a consolidation of the existing state of affairs. Whatever enthusiasm there once may have been for a looser secessionist regime has been extinguished by the bloodshed in the former Yugoslavia. The high tide of state proliferation in the post-Cold War era has already ebbed; we are now at low tide. And while there may be future high tides, they are unlikely to grow inexorably into tsunamis threatening to engulf the entire state system as we know it.

Another major component of Boniface's argument about the likelihood of state proliferation is his conception of how easy it is for secessionist movements to acquire sovereign statehood in the contemporary era. Boniface views the state as a victim of its own success and maintains that in "permitting so easily the granting of the status of statehood, we have devalued the meaning of the state." Boniface's view of the future prospects for state creation can be succinctly summed up by the title of one of Buddy Holly's first hit records: "It's So Easy."

In contrast to Boniface's "Buddy Holly" theory of statehood, I offer instead what might be termed the "Ringo Starr" theory of statehood: "It Don't Come Easy." Let's start with the case of Somalia. Boniface refers to the secessionist attempt by the Republic of Somaliland and argues that "All that remains is for the liquidation of the Somali state to be recognized." Operating from a Buddy Holly theory of statehood, Boniface dismisses "all that remains" as a mere formality, something that is ultimately inevitable whenever the international community can get around to it. In contrast, operating from a Ringo Starr theory of statehood, I see "all that remains" as more akin to a vast ocean that may never be crossed. 
The Republic of Somaliland declared its secession from Somalia in May 1991. Unlike many other secessionist movements, the Republic of Somaliland is not ethnically based. Instead, it is based on the former colonial borders of British Somaliland. The government regularly holds interclan conferences and has devised a type of consociational democracy that places a premium on the inclusion of representatives from all of Somaliland's clans in its structures. Somaliland's democratic credentials are further buttressed by the way in which its constitutional system has elaborated a separation of powers and by the promise of President Mohammed Ibrahim Egal that any future referendum on independence must secure the approval of 70 percent of the population to demonstrate minority support for the new state. All in all, the Republic of Somaliland is one of the best-run governments in the Horn of Africa.

In spite of this, and in spite of the comparative chaos, banditry, and moral bankruptcy of

The high tide of state proliferation in the post-Cold War era has already ebbed. Mogadishu, not one state has seen fit to recognize Somaliland's independence. ${ }^{10}$ Seven years after declaring its secession, "all that remains" still remains. And seven years from now, it will likely still remain.

Another relevant example here is the Turkish Republic of Northern Cyprus (TRNC). The TRNC celebrated its fifteenth anniversary in 1998 and there has been a de facto Turkish Cypriot state since 1974. The roots of Turkish Cypriot autonomy, however, go back even further than the Turkish military invasions of 1974. In his report to the UN Security Council of March 11, 1965, UN Secretary General U Thant noted that the writ of the Greek Cypriot government had not run in the local areas under Turkish Cypriot control since December 1963.

As with Somaliland, the Turkish Cypriots also have strong internal democratic credentials: general and presidential elections have been held in Northern Cyprus every five years or less since 1976. In terms of its governing abilities, the TRNC is clearly more advanced and functionally differentiated than many sovereign states. It features a mixed presidential and parliamentary system with 10 ministries, an independent judiciary, a number of extra-departmental organizations such as the State Planning Organization, and state monopolies in tobacco and citrus exports. Locally, government is provided by 26 municipalities and 186 villages divided into 3 districts. Yet rather than acquiesce to this secessionist fait accompli, as the Buddy Holly theory would predict, the international community has instead chosen an actively hostile "isolate and embargo" strategy in dealing with the 
TRNC. Once again, "all that remains" still remains, in this case nearly 25 years later. ${ }^{11}$

Perhaps the most relevant current example, however, comes from Kosovo. It doesn't take a rocket scientist to figure out that any situation in which 90 percent of the people are governed against their wishes by the remaining one-tenth is not viable in the long run. This par-

Most states are characterized by a tremendous will to live. ticular case is especially egregious since the onetenth that rules is led by Slobodan Milosevic, a man with more blood on his hands than any European leader since Hitler and Stalin. And yet, what is the first response from the United States and other Western powers to the Kosovars' demand for independence? To rule it out a priori as a completely unacceptable option. How Boniface can reconcile this ingrained reflex response from the international community with a notion of statehood devalued and easily granted is simply beyond me.

Secessionist movements may, as Boniface puts it, be "just a press release away," but sovereign statehood is not. Chechens, Kurds, southern Sudanese, Tamils, and many other groups might wish that Boniface's Buddy Holly theory of statehood were correct. Their own historical experiences, however, readily show that it is the Ringo Starr theory of statehood that dominates contemporary international relations-today as it did during the Cold War.

Perhaps more than any other part of his argument Boniface's emphasis on the economic factors behind secessionist attempts highlights the true weakness of his analysis. For Boniface, the real engines of secession today are "economic rather than nationalist or ethnic." Thus the primary stimulus that fuels secession "is not merely the defense of a threatened identity; it is pecuniary." ${ }^{2}$ Though he does not appear to be a Marxist, Boniface's thought displays a degree of economic determinism that has not been seen in international relations theory since the days of André Gunder Frank and Immanuel Wallerstein.

Obviously, economic factors do play a role in secession attempts. Boniface is probably correct that some groups will rightly or wrongly view secession as a potential route to wealth. The relationship between economics and secession is, however, much more complicated than Boniface describes. Secessionist movements have arisen in regions that are comparatively rich (Biafra, the Basque country, northern Italy) and comparatively poor (Bangladesh, Nevis, Tamil Eelam)—sometimes even within the same country (Punjab and Kashmir in India, Slovenia and Kosovo in the 
former Yugoslavia). ${ }^{13}$ Examining ethnonationalist movements in the 1980s, Ted Robert Gurr concluded that economic issues had a "negligible correlation" with secessionism. ${ }^{14}$

Going back to the Turkish Cypriot example, most estimates are that the per capita gross national product in Greek Cyprus is somewhere between three and four times higher than in Turkish Cyprus. An overall Cyprus settlement and an end to the international embargo would clearly bring economic benefits to the Turkish Cypriot population, but for nearly 25 years the Turkish Cypriots have consistently expressed a willingness to trade economic benefits for political separation or survival. Contrary to Boniface's economic determinism, the Turkish Cypriots-like the Chechens, Tamils, and other groups-clearly view economic considerations as subordinate to political goals.

Boniface's economic determinism distorts his view of not only what creates the demand for secession but also of how existing sovereign states will respond to future secessionist challengers. Drawing from the example of the Czech Republic, Boniface forecasts a generic trend in which richer regions of existing states seek to rid themselves of their poorer brethren to advance their own economic prosperity. In his vision, "prosperity has dethroned power as the primary concern of states" and "everyone wants to get rid of the poor."

This again does not stand up to empirical scrutiny. Boniface considers the objective of greater economic growth "the determining factor" behind the decision of the Soviet leadership to allow the peaceful dissolution of their union in 1991. ${ }^{15}$ Yet I wonder how this interpretation can be squared with the barbaric, inept, and anachronistic determination of Russia to compel Chechnya forcibly to remain a part of the Russian Federation against its wishes. Yes, Chechnya has some economic value as a pipeline route for Caspian oil. Surely, however, it would be ludicrous to maintain that Russia's refusal to consent to Chechen independence is based upon a consideration of that republic's economic growth potential?

In Boniface's economically determined fantasy world, glory, national sentiment, collective well-being, common interest, and the will to power "all give way before material considerations." This has clearly not been the case in Russia's reaction to the Chechen secessionist movement nor does it appear to be the case in many other examples. Boniface's scenario would see the dramatically richer Greek Cypriots gladly casting their much poorer Turkish Cypriot cousins into full independence so they would not have the burden of supporting them. Instead, the Greek Cypriot government has spent the better part of the last 25 years directing its considerable diplo- 
matic efforts toward ensuring that just such an event never comes to pass.

Much the same thing has happened in Sri Lanka. Yes, the Tamil territorial demand includes some valuable coastline and the strategic port of Trincomalee. The vast majority of Tamil lands, however, are in Sri Lanka's dry zone. If the Sinhalese majority was primarily motivated by economic considerations it would have cut the Tamils loose about 50,000 lives ago. Agreements, after all, can be reached on the use of Trincomalee as a port, and onions (a leading Tamil agricultural product) can be purchased on the world market.

Living in the richer, western part of Turkey, I have yet to encounter one single Turk who argues that western Turkey could improve its chances for European Union membership and increase its prosperity by casting off the country's poorer southeastern region. Indeed, such a suggestion is usually regarded by most Turks as somewhere between bizarre and deranged.

Sovereign states faced with secessionist movements do not evaluate them in terms of their impact on future economic growth prospects. Boniface might be correct in identifying a few cases in which the richer regions have indeed shown some interest in "getting rid" of the poor. Most states, however, are characterized by a tremendous will to live-and governments are able to parlay this global norm into concrete diplomatic, financial, and materiel support from the larger international community in their struggle against secessionist movements. Contrary to Boniface, most states thus have both the will and the ability to withstand secessionist challenges. The Czech Republic is the exception; Cyprus, Russia, Sri Lanka, and Turkey are the rule.

In addition to being wrong, Boniface's argument is dangerous. Taken seriously, his alarmist tone would encourage existing states to respond militarily to legitimate minority grievances, which are often nonsecessionist in nature and could easily be accommodated within the framework of existing territorial boundaries. If it becomes widely accepted, the false danger of "the proliferation of states" can only facilitate the tendency of existing sovereign governments to justify whatever repressive actions they take under the guise of preserving national unity. Ultimately, Boniface's overemphasis of this danger is a form of what Nigeria's Nobel laureate Wole Soyinka has termed the "language of non-negotiability." Such a language is ultimately "subversive because it is designed to stop intelligent confrontation with the very issues whose resolution is essential to guarantee the emergence or continuity of such geographical spaces as true nations." ${ }^{16}$ Ironically, such exaggerated rhetoric also reinforces the already instinctive and indiscriminate reaction in the international community against any secession attempt, regardless of the individual merits of the case. 
Boniface never hazards a guess as to the number of new states we should expect to see in the future. Perhaps this is prudent on his part. If his logic holds, however, my guess would be that we should expect to see the present 185 or more sovereign states in the world grow to somewhere between 250 and 300 sovereign states by the year 2025. If my logic holds, however, we should only expect to see about 200 sovereign states by the year 2025 , and we may not even see that many. In other words, the "proliferation of states" is a non-issue.

\section{Notes}

1. Pascal Boniface, "The Proliferation of States," The Washington Quarterly 21, no. 3 (Summer 1998): 111-127.

2. Ken Saro-Wiwa, A Month and a Day (London: Penguin, 1995), 154. The Ogoni Bill of Rights and its addendum can be found on 67-70 and 89-92.

3. Ted Robert Gurr, "Peoples Against States: Ethnopolitical Conflict and the Changing World System," International Studies Quarterly 38 no. 3 (September 1994): 355.

4. For a more balanced assessment of the effects of a declining external threat environment on state cohesion, see Michael C. Desch, "War and Strong States, Peace and Weak States?" International Organization 50 no. 2 (Spring 1996): 237-268.

5. For more on this, see Scott Pegg, International Society and the De Facto State (Aldershot, England: Ashgate, 1998), 137-143.

6. Boniface, "The Proliferation of States," 113.

7. J. Samuel Barkin and Bruce Cronin, "The State and the Nation: Changing Norms and the Rules of Sovereignty in International Relations," International Organization 48 no. 1 (Winter 1994): 107-130.

8. Boniface, "The Proliferation of States," 111.

9. Ibid., 112.

10. For more on the Republic of Somaliland, see Pegg, International Society, 85-97.

11. For more on the TRNC, see ibid., 98-113.

12. Boniface, "The Proliferation of States," 123 and 114.

13. For more on this, see Milica Zarkovic Bookman, The Economics of Secession (New York: St. Martin's Press, 1992), 94-95.

14. Gurr, "Peoples Against States," 358.

15. Boniface, "The Proliferation of States," 115.

16. Wole Soyinka, The Open Sore of a Continent: A Personal Narrative of the Nigerian Crisis (Oxford: Oxford University Press, 1996), 33. 